\title{
A body-based art
}

In Whatever Houses We May Visit:

An Anthology of Poems That Have Inspired Physicians

Michael A. LaCombe MD and Thomas V. Harman, editors.

American College of Physicians Press; 2008. 257 pp $\$ 34.95$

$\mathrm{W}$ hen I was a member of the Vancouver Industrial Writers' Union in the early 1980s, the "industrial" of our name was a misnomer. Three of us, almost half, worked in the healing professions. This is unsurprising given that poetry has so little to do with writing: like doctoring, it is body-based. That's why there are so many physician poets. It is difficult to care for bodies without encountering the ghost in the machine.

In his introduction to this anthology, Michael V. Lacombe writes: "the majority of these poems were sent to us by physicians from all over the world in response to 'Call for Poetry' notices sent to virtually every medical journal published in English and a few that are not."

As expected, there are great and justly famous poems here by poets who are known by their last names: Basho, Wordsworth, Tennyson, Dickinson, Yeats, Cummings, Auden. There are poems by doctors we know (William Carlos Williams, Rafael Campo, Dannie Abse) and by many medical workers we don't.

There are dreadfully sentimental poems here. Their authors may be forgiven, for they have their hands full. They are busy, and the work is overwhelming. Who cares if the poem gets an $\mathrm{A}+$ when it gushes with the sad truth? Are "bad" poems dreadful, or is it that they fill us with dread? How grateful, then, are we to laugh at death. For there is needed humour here also. Thus, Ogden Nash:

\section{Go hang yourself, you old M.D.!}

You shall no longer sneer at me.

Pick up your hat and stethoscope,

Go wash your mouth with laundry soap;

I contemplate a joy exquisite

In never paying you for your visit.

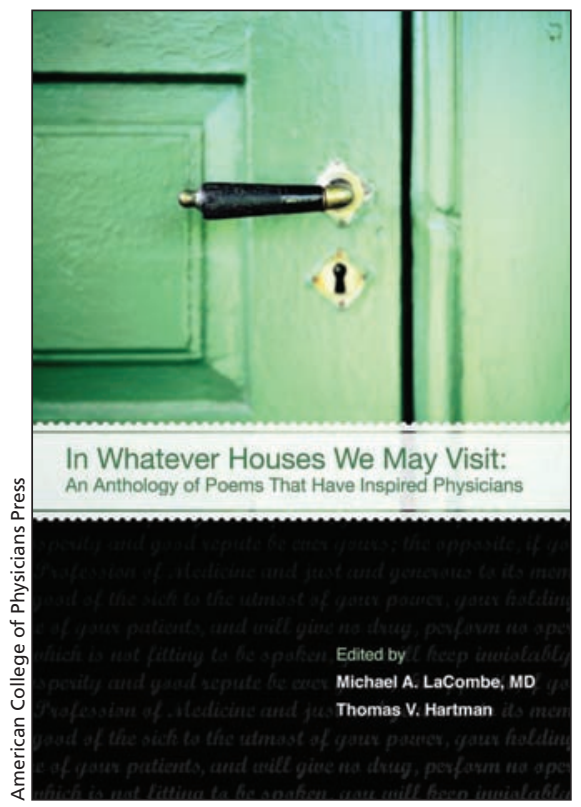

The poet most included here is Miroslav Holub, the Czech immunologist. Who is missing? Well, I'm surprised there aren't any poems by Thomas Lynch, the Michigan funeral director/writer.

There have been many such anthologies. Gerald Weissmann writes in Blood and Bones: Poems by Physicians (JAMA Press, 1998) that "More doctors write poetry than read it." Nevertheless, other titles you might seek out are Body Language: Poems of the Medical Training Experience (BOA Editions, 2006), or Between The Heartbeats (University of Iowa Press, 1995).

Can any other profession boast such literary output? Surely, there have been lawyer poets (Charles Reznikoff, A. M. Klein). There proba- bly are collections of poems about or by lawyers, although the concept seems funny somehow.

The subtitle of this anthology says that the poems here have "inspired" physicians, which I take to mean that favourite poems, stuck above desks and on bulletin boards, have been turned to for comfort. If so, then it is good to have them all together. They have proved their worth.

But ultimately a poem cures not death, and it is in acutely saying so that we may take brief solace. Here are the last words of William Carlos Williams's English grandmother:

we passed a long row of elms. She looked at them awhile out of the ambulance window and said,

What are those

fuzzy looking things out there?

Trees? Well, I'm tired

of them and rolled her head away.

Such good anthologies as this also serve a further purpose: they inspire doctors and nurses and other medical workers - who may have never thought to do so - to write their own poems about their own work experiences.

\section{Phil Hall MA \\ Poet \\ Perth, Ont.}

Mr. Hall's book of poems, An Oak Hunch (Brick Books), was nominated for the Griffin Poetry Prize in 2006.

\section{Orbinski awarded book prize}

Dr. James Orbinski, the former international president of Médecins Sans Frontières, has been awarded the Shaughnessy Cohen Prize for nonfiction, for An Imperfect Offering: Humanitarian Action in the 21st Century (CMAJ 2008;178:1192). The $\$ 25000$ prize, which recognizes a book that enhances our understanding of an issue and has the potential to influence Canadian political life, was presented March 4 at the Politics and the Pen ceremony in Ottawa, Ontario. - CMAJ 